\title{
ASSESSING THE ACTIVITIES OF LOCAL ADMINISTRATIONS FROM THE PERSPECTIVE OF SOCIAL PARTICIPATION WITHIN CITIES WITH POVIAT STATUS IN THE PODKARPACKIE PROVINCE OF POLAND
}

Social participation is most often perceived as a means of external cooperation between public authorities and citizens. It should be based on a common and consensual identification of problem issues and their resolution in a meaningful way through the exchange and justification of reasons, mutual education, and training and acquisition of civic competences. The basis of social participation in the local dimension is the use of citizens' rights. The active attitude of citizens is an important guarantor in building a civic commune in which residents are not the object but the subject of public policy. Therefore, social participation favors building relations between self-government and citizens based on the principle of partnership and participation in local decision-making processes.

The purpose of the article is to evaluate the activity and involvement of local administration in creating appropriate conditions for the active participation of citizens in the field of social participation. In order to achieve this goal, surveys were conducted among the inhabitants of four cities with poviat status in Podkarpackie Province, Poland, namely, Rzeszów, Krosno, Przemyśl, and Tarnobrzeg. The research has shown that the local community of Podkarpackie cities rarely uses the various forms of social participation offered to them by the local administration. This is why the administration's activities should focus on making residents aware of the benefits of participation. Providing residents with relevant information on the principles, forms, or methods of participation may prejudge the quality of life in a given local government and the course of its development.

Keywords: Local administration, social participation, cooperation, inhabitant's activity.

\section{INTRODUCTION}

In Poland, there has been a growing interest of citizens in public affairs, especially at the local level, for several years now. The issue of citizens' involvement in the process of

\footnotetext{
${ }^{1}$ Mariola Grzebyk, DSc, PhD, Eng. Associate Prof., Institute of Economics and Finance, University of Rzeszów, M. Ćwiklińskiej 2 Str., 35-601 Rzeszów, Poland; e-mail: mgrzebyk6@gmail.com. ORCID: 0000-0003-1107-0250 (corresponding author).

2 Agata Pierścieniak, DSc, PhD, Eng. Associate Prof., Faculty of Management and Economics, Gdansk University of Technology, Narutowicza 11/12 Str., 80-233 Gdansk, Poland; e-mail: agata.pierscieniak@gmail.com. ORCID: 0000-0002-1724-6766.
} 
territorial unit management depends on the level of social development of a given community. The aspect of citizen empowerment, giving them appropriate rights, competences and duties is one of the key elements of participatory democracy, its main strength and guarantee of effectiveness.

From a democratic perspective, citizen participation is considered a valuable element of democratic citizenship and democratic decision-making. Participatory and deliberative democrats, in particular, argue that citizen participation has positive effects on the quality of democracy (Michels et al., 2010).

Social participation is primarily conducive to building relations between local government and citizens based on the principle of partnership and participation in local decision-making processes. Its extensive use in local government practice fosters the building of a civic community in which residents are not the object but the subject of public policy. Public participation brings the government closer to the people. It enables citizens to set policy goals and priorities, oversee the actions of the politicians and administrators and hold them accountable for their actions, express points of view, share information and point to their needs and problems, get involved in the decision-making process and many others (Grzebyk et.al., 2019; Harula and Radu, 2010).

The emphasis on the importance of social participation can also be found in EU regulations or OECD reports (2001), which have been translated into national documents (including legal ones), and may also take the form of good practices or recommendations.

The aim of the article is to evaluate the activity and involvement of local administration in creating appropriate conditions for active participation of residents in the field of social participation. Its implementation required answers to the following research questions:

- How do the inhabitants of the examined cities perceive the activity of local administration?

- Do the residents know the forms and tools used by local authorities for public participation?

- Which of the forms of participation are considered the most effective by the inhabitants?

- What are the main barriers to public participation according to the residents?

The spatial scope of the research covers all cities with poviat status located in Podkarpackie Province, Poland, namely Krosno, Przemyśl, Rzeszów and Tarnobrzeg33.

In order to implement the research assumptions of the article, it has been divided into several parts, including a literature review, surveys, analysis of results and conclusions. In order to determine the state of social participation in the mentioned town cities, one of the basic research techniques, i.e. surveys, was used. By using this technique, it was possible to reliably gather and classify data related to the phenomenon of social participation. In addition, the information obtained allowed to determine the scale, degree and dynamics of social participation.

The survey was conducted on 100 people in each city. The criterion for the selection of respondents was the length of time they lived in a given locality, which was at least three years. Living in a given city for a longer period of time allowed inhabitants to be more involved in public affairs. The survey contained a number of both open and closed questions

\footnotetext{
${ }^{3}$ In the research part, certain abbreviations have been used to facilitate analysis and for better transparency. The following markings were used: $\mathrm{K}$ - Krosno, P - Przemyśl, RZ - Rzeszów and $\mathrm{T}-$ Tarnobrzeg.
} 
to obtain the data necessary to recognize and present the studied phenomenon on a local scale.The article is a continuation of the research on social participation conducted by the authors in the cities earlier mentioned.

\section{TASKS AND ROLE OF LOCAL ADMINISTRATION IN THE FIELD OF SOCIAL PARTICIPATION}

Cities with poviat status are self-governing units that perform both commune and poviat tasks (Kaczmarek, 2016) in various spheres, including communal, social or infrastructural ones. Each of these spheres determines the quality of everyday life of the vast majority of the population and has an impact on the socio-economic growth of the region. Local administration has a service-oriented character towards its inhabitants, so it cannot remain "deaf" to opinions and needs expressed from below. Membership participation has become a veritable strategy for empowerment in the development scene. The participation of community members in development activities enhances capacity building (Uche et. al., 2019).

Social participation is perceived as a way of external cooperation (Kakumba, Nsingo, 2008) between public authorities and residents. It should be based on common and consensual identification of problematic issues and a mutually satisfactory solution to them in a meaningful way, through exchange and justification of reasons, two-way education and training and acquisition of civic competences (Alexiu et.al, 2011; McGann, 2006). Creighton (2005) argues that "public participation is the process by which public concerns, needs and values are incorporated into the governmental and corporate decision-making. It is a two-way communication and interaction, with the overall goal of better decisions that are supported by the public.

Bradbury et al. (1999) argued that public participation should be viewed as a dialogue or a communicative act in which fair and competent processes are emphasized. King et. al. (1998) adds that making decisions in public administration without public participation is ineffective.

Advocates for participation note that policy and development which adopt a bottom-up framework where local communities are actively involved in decision-making, better facilitate the achievement of target objectives.

The basis for social participation in the local dimension is the use of citizens' rights (e.g. direct decision-making through local elections or referendums). As some authors note (Edelenbos, Klijn, 2005; Fishkin, 2009; Harula, Radu, 2010) voting is not the only form of public participation: public debates, public meetings, citizens juries, citizens polls, written notices, comments and suggestions, mailings etc. do not even manage to exhaust the list of all possible instruments either citizens or officials can use in order to enhance the public participation dimension of the policy making process.

Some authors suggest (Innes, Booher, 2007) that participation should be understood as a multi $\square$ way set of interactions among citizens and other players who together produce outcomes. Authentic dialogue, networks and institutional capacity are the key elements. Next steps involve developing an alternative practice framework, creating forums and arenas, adapting agency decision processes, and providing training and financial support.

Brynard (1996) outlines the following as the objectives of citizen participation: provide information to citizens; get information from the citizens; improve public decisions, programs, projects, and services; enhance acceptance of public decisions, programs, 
projects, and services; supplement public agency work; alter political power patterns and resource allocation; protect individual and minority group rights and interests; and delay or avoid complicating difficult public decisions.

Information dissemination is the simplest form of participation which translates into informing citizens about decisions that affect them. The information function should be a standard procedure for the functioning of public administration (Kasymova, 2014). In Poland, information is the basic duty of local authorities and is an important instrument for building trust between local authorities and citizens. Local authorities have the task of informing the inhabitants about the actions taken. The increase in factual and complete information leads to increased public trust in the work of local administration. The information process itself can be carried out through such channels as newsletters, brochures, press articles or websites.

Consultation is the next stage of engagement, which is not binding though, but takes into account the opinions of the citizens. At this stage, the decisions taken by the authorities are consulted with the citizens before approval. Consultations take an active form and may result in a change in the decision of the authorities during the chosen discussions. The areas which local authorities have a top-down obligation to consult residents include: Preparing a study of conditions and directions of spatial development of the commune and local spatial development plans, as well as creating auxiliary units of the commune. The use of public consultations at the planning stage facilitates the implementation of projects at a later stage, while mitigating potential local conflicts and disputes. An element that may prevent the authorities from conducting public consultations may be its time consumption, relatively high costs, low culture of consultations or lack of interest by the residents (Kasymova, Schachter, 2014).

The acceptance of co-decision making is the strongest incentive for the participation and engagement of the local community in building social democracy together (Irvin and Stansbury, 2004). It assumes active participation of citizens at the stages of making public decisions as well as in their implementation. It is a relationship that focuses on involving NGOs, private sector entities and the citizens' initiative in eliminating local problems and determining key decisions relating to the local community. It is a deliberate procedure whose intention is to effectively manage the common good by public authorities. The participation of local citizens is intended to make rational decisions.

Given the intensity of participation, it should be noted that information is characterized by low intensity of social activity, medium and high intensity for consultation, and for codecision respectively. It is widely believed that the participation process is seen to be effective if all three of the above-mentioned forms of participation, i.e. information sharing, consultation and co-decision taking, are fulfilled by the parties engaged in the participation process (Wójcicki, 2013).

\section{STATE AND ASSESSMENT OF LOCAL ADMINISTRATION'S ACTIVITIES BY INHABITANTS IN THE PROCESS OF SOCIAL PARTICIPATION}

This part of the article will present the results of surveys conducted among the inhabitants of the cities examined in Podkarpackie Province. An important constituent of the local administration is the establishment of a social participation unit within its set up. Surveys show that respondents of the cities covered lack knowledge concerning the functioning of the social participation unit in their city council offices. Consequently, the 
respondents evaluated the effectiveness of the forms of participation applied by the local office in their city (Table 1). Analysis of the results shows that information sharing and consultation was rated by residents mostly as moderately effective. According to the respondents, co-decision taking is little or, at most, moderately effective.

Table 1. Evaluation of the effectiveness of individual forms of social participation used by a given city council

\begin{tabular}{|l|l|c|c|c|c|}
\hline \multirow{2}{*}{ FORM } & \multirow{2}{*}{ RATING } & \multicolumn{4}{|c|}{ ANSWER STRUCTURE [\%] } \\
\cline { 3 - 6 } & & $\mathbf{K}$ & $\mathbf{P}$ & $\mathbf{R Z}$ & $\mathbf{T}$ \\
\hline \multirow{3}{*}{$\begin{array}{l}\text { INFORMATION } \\
\text { SHARING }\end{array}$} & I have no opinion & 22.5 & 15.0 & 15.0 & 17.5 \\
\cline { 2 - 6 } & Not effective & 12.5 & 22.5 & 5.0 & 7.5 \\
\cline { 2 - 6 } & Medium effective & $\mathbf{4 0 . 0}$ & $\mathbf{5 7 . 5}$ & 10.0 & $\mathbf{6 2 . 5}$ \\
\cline { 2 - 6 } & Highly effective & 25.0 & 5.0 & $\mathbf{7 0 . 0}$ & 12.5 \\
\hline \multirow{4}{*}{ CONSULTATION } & I have no opinion & 25.0 & 22.0 & 12.5 & 15.0 \\
\cline { 2 - 6 } & Not effective & $\mathbf{3 2 . 5}$ & 5.0 & 35.0 & 17.5 \\
\cline { 2 - 6 } & Medium effective & 27.5 & $\mathbf{7 0 . 0}$ & $\mathbf{4 2 . 5}$ & $\mathbf{5 7 . 5}$ \\
\cline { 2 - 6 } & Highly effective & 15.0 & 2.5 & 10.0 & 10.0 \\
\hline TAKING & I have no opinion & $\mathbf{4 7 . 5}$ & 20.0 & 17.5 & 12.5 \\
\cline { 2 - 6 } & Not effective & 27.5 & $\mathbf{4 7 . 5}$ & $\mathbf{6 7 . 5}$ & 10.0 \\
\cline { 2 - 6 } & Medium effective & 12.5 & 20.0 & 15.0 & $\mathbf{7 0 . 0}$ \\
\cline { 2 - 6 } & Highly effective & 12.5 & 12.5 & 0.0 & 7.5 \\
\hline
\end{tabular}

Source: Own study based on research results.

Table 2 presents the most common reasons for not responding to events organized by the local public administration. Research results show that the most frequently mentioned reasons include: lack of time, insufficient promotion of events, lack of sufficient motivation, difficulty getting to places where the events take place and the limited number of events that are relevant to the interests of residents. The data is similar to an earlier research carried out by the Public Opinion Research Center, May 2011, on the social activity of Poles - their level of involvement and motivation. A comparison of both studies indicate that the decisive reason, both a few years ago and now, for the low engagement of residents in social activities is the lack of time ${ }^{4}$.

Table 3 shows the assessment of the form and scope of information expected by residents from their city council. Most respondents, in all four cities, mostly expect information regarding the schedules of their activities, working hours and contacts, as well as the theme of festivities and events planned for the city, including job offers from city councils.

\footnotetext{
${ }^{4}$ https://www.cbos.pl [Access: 30.11.2019].
} 
Table 2. The most common reasons for not being involved in events organized by the local public administration

\begin{tabular}{|l|c|c|c|c|}
\hline \multicolumn{1}{|c|}{$\begin{array}{c}\text { REASON FOR LACK OF } \\
\text { COMMITMENT }\end{array}$} & \multicolumn{4}{c|}{ ANSWER STRUCTURE [\%] } \\
\cline { 2 - 5 } & K & $\mathbf{P}$ & $\mathbf{R Z}$ & T \\
\hline Lack of time & 67.5 & 70.0 & $\mathbf{8 0 . 0}$ & $\mathbf{8 7 . 5}$ \\
\hline $\begin{array}{l}\text { Difficulties of accessing places, where } \\
\text { events take place }\end{array}$ & 17.5 & 15.0 & 12.5 & 10.0 \\
\hline $\begin{array}{l}\text { Limited events that are relevant to the } \\
\text { interests of residents }\end{array}$ & 10.0 & 17.5 & 17.5 & 17.5 \\
\hline Insufficient promotion & 40.0 & 25.0 & 25.0 & 5.0 \\
\hline Insufficient motivation & $\mathbf{8 7 . 5}$ & $\mathbf{7 7 . 5}$ & 37.5 & 77.5 \\
\hline Costs & 5.0 & 2.5 & 0.0 & 7.5 \\
\hline Age & 10.0 & 10.0 & 10.0 & 12.5 \\
\hline Health & 2.5 & 7.5 & 0.0 & 7.5 \\
\hline
\end{tabular}

Source: Own study based on research results.

Table 3. The scope of information expected by residents from the city council

\begin{tabular}{|l|c|c|c|c|}
\hline \multirow{2}{*}{ SCOPE OF INFORMATION } & \multicolumn{4}{c|}{ *ANSWER STRUCTURE [\%] } \\
\cline { 2 - 5 } & $\mathbf{K}$ & $\mathbf{P}$ & $\mathbf{R Z}$ & T \\
\hline News of city council activities & $\mathbf{1 0 0 . 0}$ & $\mathbf{8 5 . 0}$ & $\mathbf{9 5 . 0}$ & $\mathbf{9 2 . 5}$ \\
\hline Working time and contact & 80.0 & 62.5 & 72.5 & 75.0 \\
\hline Education & 17.5 & 20.0 & 25.0 & 30.0 \\
\hline Photo galleries and cinemas & 7.5 & 0.0 & 2.5 & 25.0 \\
\hline Information concerning participatory budget & 15.0 & 12.5 & 7.5 & 7.5 \\
\hline $\begin{array}{l}\text { Information about festivals and events in the } \\
\text { city }\end{array}$ & 82.5 & 52.5 & 32.5 & 52.5 \\
\hline Information on public consultations & 17.5 & 5.0 & 7.5 & 2.5 \\
\hline Information on regulations / office duties. & 52.5 & 27.5 & 40.0 & 7.5 \\
\hline Job offers & 70.0 & 45.0 & 52.5 & 77.5 \\
\hline City real estate offers & 15.0 & 17.5 & 22.5 & 15.0 \\
\hline Research publications & 5.0 & 0.0 & 0.0 & 5.0 \\
\hline Revitalization & 35.0 & 17.5 & 15.0 & 55.0 \\
\hline Matters being executed & 12.5 & 45.0 & 20.0 & 32.5 \\
\hline Authorities & 7.5 & 2.5 & 0.0 & 2.5 \\
\hline
\end{tabular}

* The total of responses do not add up to $100 \%$ due to the possibility of choosing a maximum of 3 answers by respondents

Source: Own study based on research results.

Table 4 presents the information tools most often offered by the city councils and most readily used by residents. The residents use websites, social networking sites, the Public Information Bulletin, the Council's service catalogue, posters, folders, leaflets, information placed on noticeboards and public buildings, resident's forums and local mass media. 
Table 4. Information tools most often used by residents to assess information offered by a given city council

\begin{tabular}{|l|c|c|c|c|}
\hline \multirow{2}{*}{ TOOLS USED } & \multicolumn{4}{c|}{ ANSWER STRUCTURE [\%] } \\
\cline { 2 - 5 } & $\mathbf{K}$ & $\mathbf{P}$ & $\mathbf{R Z}$ & T \\
\hline Public Information Bulletin (BPI) & 75.0 & 65.0 & 82.5 & 92.5 \\
\hline Cyclical reports on the authority's activities & 7.5 & 10.0 & 5.0 & 5.0 \\
\hline Information from the council session & 10.0 & 2.5 & 7.5 & 10.0 \\
\hline Office services catalogue & 40.0 & 47.5 & 37.5 & 7.5 \\
\hline Posters, folders, leaflets & 52.5 & 40.0 & 45.0 & 15.0 \\
\hline Information points in government offices & 20.0 & 30.0 & 27.5 & 20.0 \\
\hline Websites & $\mathbf{1 0 0 . 0}$ & $\mathbf{1 0 0 . 0}$ & $\mathbf{1 0 0 . 0}$ & 97.5 \\
\hline $\begin{array}{l}\text { Information on noticeboards and public } \\
\text { buildings }\end{array}$ & 30.0 & 32.5 & 22.5 & 67.5 \\
\hline Office hours of the executive & 0.0 & 0.0 & 0.0 & 2.5 \\
\hline Residents' forums & 77.5 & 42.5 & 90.0 & 97.5 \\
\hline Helplines & 0.0 & 0.0 & 0.0 & 0.0 \\
\hline Local mass media & 77.5 & 57.5 & 92.5 & 2.5 \\
\hline Mailing, newsletter & 10.0 & 0.0 & 5.0 & 2.5 \\
\hline Social media & $\mathbf{1 0 0 . 0}$ & 77.5 & $\mathbf{1 0 0 . 0}$ & $\mathbf{1 0 0 . 0}$ \\
\hline $\begin{array}{l}\text { Meetings with representatives of opinion } \\
\text { leaders }\end{array}$ & 0.0 & 0.0 & 0.0 & 30.0 \\
\hline SMS notification system & 0.0 & 0.0 & 0.0 & 7.5 \\
\hline
\end{tabular}

* The total of responses do not add up to $100 \%$ due to the possibility of choosing a maximum of 3 answers by respondents

Source: Own study based on research results.

Public consultations are another form of local community involvement in the cities' social life (Table 5). The information obtained shows that the majority of the responding residents do not participate in public consultations. In Krosno, every third respondent participates in social consultations, while in Przemyśl and Tarnobrzeg every eighth person participating in the survey.

Table 5. Participation of residents in social consultations organized by local authorities

\begin{tabular}{|c|c|c|c|c|}
\hline \multirow{2}{*}{ SPECIFICATION } & \multicolumn{4}{|c|}{ STRUKTURA ODPOWIEDZI [\%] } \\
\cline { 2 - 5 } & K & P & RZ & T \\
\hline YES & 30.0 & 12.5 & 17.5 & 12.5 \\
\hline NO & $\mathbf{7 0 . 0}$ & $\mathbf{8 7 . 5}$ & $\mathbf{8 2 . 5}$ & $\mathbf{8 7 . 5}$ \\
\hline
\end{tabular}

Source: Own study based on research results. 
Respondents, participants in public consultations, were also asked about their degree of involvement in this form of social participation offered by city councils (Table 6). All respondents participating in public consultations organized by the city councils rated their degree of involvement as incidental rather than active.

Table 6. Degree of local community involvement in social consultations

\begin{tabular}{|c|l|c|c|c|c|}
\hline \multirow{2}{*}{ FORM } & \multirow{2}{*}{ Ocena } & \multicolumn{4}{|c|}{ ANSWER STRUCTURE [\%] } \\
\cline { 3 - 6 } & & $\mathbf{K}$ & $\mathbf{P}$ & $\mathbf{R Z}$ & $\mathbf{T}$ \\
\hline \multirow{2}{*}{ CONSULTATION } & Incidental participation & $\mathbf{2 2 . 5}$ & $\mathbf{1 0 . 0}$ & $\mathbf{1 2 . 5}$ & $\mathbf{7 . 5}$ \\
\cline { 2 - 6 } & Active participation & 7.5 & 2.5 & 5.0 & 5.0 \\
\hline
\end{tabular}

Source: Own study based on research results.

In turn, the results of the research into aspects of consultations in which residents participate are presented in Table 7. Areas of consultation in which inhabitants of all cities with poviat status in the Podkarpackie Province most often take part in include: consulting draft resolutions, development strategies and social problems. In Krosno and Tarnobrzeg, respondents are also involved in social consultations regarding education and education. In Krosno and Rzeszów, the studied local community participates in social consultations that relate to infrastructure investments.

Table 7. Participation of residents in individual areas of consultation

\begin{tabular}{|l|c|c|c|c|}
\hline \multirow{2}{*}{ CONSULTATION AREA } & \multicolumn{4}{|c|}{ ANSWER STRUCTURE [\%]* } \\
\cline { 2 - 5 } & $\mathbf{K}$ & $\mathbf{P}$ & $\mathbf{R Z}$ & $\mathbf{T}$ \\
\hline Public safety & 0.0 & 0.0 & 0.0 & 0.0 \\
\hline Education and education & $\mathbf{2 7 . 5}$ & 0.0 & 0.0 & $\mathbf{7 . 5}$ \\
\hline Infrastructure investments & $\mathbf{2 0 . 0}$ & 0.0 & 2.5 & 0.0 \\
\hline Consulting draft resolutions & 5.0 & $\mathbf{1 0 . 0}$ & $\mathbf{1 0 . 0}$ & 5.0 \\
\hline Environmental Protection & 0.0 & 0.0 & 0.0 & 0.0 \\
\hline Social problems & $\mathbf{1 5 . 0}$ & $\mathbf{7 . 5}$ & 25 & 0.0 \\
\hline Sport and Recreation & 0.0 & 0.0 & 0.0 & 0.0 \\
\hline Development strategy & 7.5 & $\mathbf{7 . 5}$ & $\mathbf{7 . 5}$ & $\mathbf{1 2 . 5}$ \\
\hline Tourism & 0.0 & 0.0 & 0.0 & 0.0 \\
\hline Public services & 0.0 & 0.0 & 0.0 & 0.0 \\
\hline Spatial planning & 12.5 & 5.0 & 0.0 & 5.0 \\
\hline
\end{tabular}

* The total of responses do not add up to $100 \%$ due to the possibility of choosing max 3 answers by respondents

Source: Own study based on research results.

Table 8 presents the tools applied in public consultation most recognizable by residents. The responses include, amongst others, direct meetings with residents and NGOs, meetings with specific target groups and meetings with expert or problem teams. 
Table 8. Citizens' recognition of social consultation tools used by city councils

\begin{tabular}{|l|c|c|c|c|}
\hline \multirow{2}{*}{$\begin{array}{c}\text { LIST OF SOCIAL } \\
\text { CONSULTATION TOOLS }\end{array}$} & \multicolumn{4}{c|}{ ANSWER STRUCTURE [\%] } \\
\cline { 2 - 5 } & $\mathbf{K}$ & $\mathbf{P}$ & $\mathbf{R Z}$ & $\mathbf{T}$ \\
\hline Direct meetings with residents & $\mathbf{3 0 . 0}$ & 0.0 & $\mathbf{1 7 . 5}$ & 10.0 \\
\hline $\begin{array}{l}\text { Direct meetings with } \\
\text { non-governmental organizations }\end{array}$ & 10.0 & $\mathbf{1 0 . 0}$ & 7.5 & 7.5 \\
\hline Online consultation, sms & 0.0 & 0.0 & 0.0 & 10.0 \\
\hline Opinion poll & 0.0 & 2.5 & 0.0 & 0.0 \\
\hline Meetings with specific target groups & 2.5 & 7.5 & 5.0 & $\mathbf{1 2 . 5}$ \\
\hline $\begin{array}{l}\text { Meetings with expert and problem } \\
\text { teams }\end{array}$ & 7.5 & 2.5 & 2.5 & 0.0 \\
\hline Cooperation triangle & 0.0 & 0.0 & 0.0 & 0.0 \\
\hline
\end{tabular}

* The total of responses do not add up to $100 \%$ due to the possibility of choosing max 3 answers by respondents

Source: Own study based on research results.

Another form of participation of residents in social life is co-decision taking. The participation of inhabitants in this form is presented in Table 9. The vast majority of responding residents of the cities covered do not participate in the form of social participation, namely co-decision taking. This is confirmed by the results of research on the public activity of Poles. According to the European Social Survey, in 2005 the average value of the public activity indicator in Poland was 3-4 times lower than the European average ${ }^{5}$.

Table 9. Share of residents in the form of co-decision taking

\begin{tabular}{|c|c|c|c|c|}
\hline \multirow{2}{*}{ SPECIFICATION } & \multicolumn{4}{|c|}{ ANSWER STRUCTURE [\%] } \\
\cline { 2 - 5 } & $\mathbf{K}$ & $\mathbf{P}$ & $\mathbf{R Z}$ & $\mathbf{T}$ \\
\hline YES & 7.5 & 7.5 & 10.0 & 5.0 \\
\hline NIE & $\mathbf{9 2 . 5}$ & $\mathbf{9 2 . 5}$ & $\mathbf{9 0 . 0}$ & $\mathbf{9 5 . 0}$ \\
\hline
\end{tabular}

Source: Own study based on research results.

Persons participating in the analyzed form of participation also identified other areas of this cooperation. The data is presented in Table 10. The areas of co-decision taking in which the inhabitants of all cities with poviat rights of the Podkarpackie Province take part are: the civic/participatory budget, social welfare, local development and spatial development. In addition, social issues are important in Krosno, and education is important in Tarnobrzeg.

The co-decision taking tools used by the residents, which are used by the city hall, are presented in Table 11. A common consensus tool used by all city councils is to reach a consensus. In addition, in Krosno, the local community is oriented towards the involvement of auxiliary units and meetings with opinion leaders. In Tarnobrzeg, respondents know about decentralization of powers towards auxiliary units.

\footnotetext{
${ }^{5}$ http://eu.ngo.pl/files/ue.ngo.pl/public/materialy_analizy/przewodnik_ost.pdf [Access: 28.11.2019].
} 
Table 10. Participation of residents in co-decision by individual areas

\begin{tabular}{|l|c|c|c|c|}
\hline \multirow{2}{*}{ CO-DECISION TAKING AREA } & \multicolumn{4}{|c|}{ ANSWER STRUCTURE [\%]* } \\
\cline { 2 - 5 } & K & P & RZ & T \\
\hline Public safety & 0.0 & 0.0 & 0.0 & 0.0 \\
\hline Civic/participatory budget & 2.5 & $\mathbf{7 . 5}$ & $\mathbf{7 . 5}$ & 2.5 \\
\hline Education & 0.0 & 0.0 & 0.0 & 5.0 \\
\hline Infrastructure investments & 0.0 & 0.0 & 0.0 & 0.0 \\
\hline Social care & $\mathbf{7 . 5}$ & 2.5 & 2.5 & $\mathbf{5 . 0}$ \\
\hline Local development & 5.0 & $\mathbf{7 . 5}$ & 2.5 & $\mathbf{5 . 0}$ \\
\hline Technical services & 0.0 & 0.0 & 0.0 & 0.0 \\
\hline Spatial planning & 5.0 & 2.5 & 5.0 & 2.5 \\
\hline Social issues & 2.5 & 0.0 & 0.0 & 0.0 \\
\hline
\end{tabular}

* The structure of answers does not add up to $100 \%$ due to the possibility of choosing max 3 answers by respondents

Source: Own study based on research results.

Table 11. Co-decision taking tools known by residents used by the city council

\begin{tabular}{|l|c|c|c|c|}
\hline \multirow{2}{*}{$\begin{array}{c}\text { CO-DECISION TAKING TOOLS } \\
\text { CATALOG }\end{array}$} & \multicolumn{4}{c|}{ ANSWER STRUCTURE [\% } \\
\cline { 2 - 5 } & K & P & RZ & T \\
\hline Direct resolution initiative & 0.0 & 0.0 & 0.0 & 0.0 \\
\hline $\begin{array}{l}\text { Decentralization of powers towards } \\
\text { auxiliary units }\end{array}$ & 0.0 & 0.0 & 0.0 & $\mathbf{5 . 0}$ \\
\hline Local Citizens' Councils & 0.0 & 0.0 & 0.0 & 0.0 \\
\hline Negotiations & 0.0 & 0.0 & 0.0 & 0.0 \\
\hline Referendum & 0.0 & 0.0 & 0.0 & 0.0 \\
\hline Consensus & 5.0 & $\mathbf{1 0 . 0}$ & $\mathbf{1 0 . 0}$ & 5.0 \\
\hline $\begin{array}{l}\text { Involvement in the activities of ancillary } \\
\text { units }\end{array}$ & $\mathbf{1 7 . 5}$ & 0.0 & 0.0 & 0.0 \\
\hline Meeting with opinion leaders & 5.0 & 0.0 & 0.0 & 00 \\
\hline
\end{tabular}

* The structure of answers does not add up to $100 \%$ due to the possibility of choosing max 3 answers by respondents

Source: Own study based on research results.

The respondents were also asked about the barriers hindering social participation. The results of the survey are presented in Table 12. The main barriers to social participation that limit cooperation with social administration according to residents include: lack of interest of residents, lack of citizen awareness, lack of knowledge of residents about their rights, lack of financial resources, lack of interest in cooperation among public administration employees and poor communication between the office and the residents. Interestingly, the residents of Przemyśl, Rzeszów and Tarnobrzeg also mentioned the lack of a suitable room within the office building, although it exists in all offices. This indicates a poor understanding of the office's activities in this area by the respondents. 
Table 12. Barriers of social participation

\begin{tabular}{|l|c|c|c|c|}
\hline \multirow{2}{*}{ BARRIERS } & \multicolumn{4}{|c|}{ ANSWER STRUCTURE [\%] } \\
\cline { 2 - 5 } & $\mathbf{K}$ & $\mathbf{P}$ & $\mathbf{R Z}$ & $\mathbf{T}$ \\
\hline Lack of interest of residents & 65.0 & $\mathbf{8 0 . 0}$ & $\mathbf{7 7 . 5}$ & $\mathbf{9 0 . 0}$ \\
\hline Lack of financial resources & 27.5 & 45.0 & 12.5 & 50.0 \\
\hline No public internet access & 0.0 & 0.0 & 2.5 & 5.0 \\
\hline $\begin{array}{l}\text { Lack of appropriate space in } \\
\text { the office buildings }\end{array}$ & 0.0 & 12.5 & 30.0 & 9.0 \\
\hline $\begin{array}{l}\text { No specific communication } \\
\text { procedures }\end{array}$ & 10.0 & 5.0 & 0.0 & 7.5 \\
\hline $\begin{array}{l}\text { Lack of interest in civic duties } \\
\text { by residents }\end{array}$ & $\mathbf{8 5 . 0}$ & 72.5 & 62.5 & 37.5 \\
\hline $\begin{array}{l}\text { Lack of knowledge of } \\
\text { residents about their rights }\end{array}$ & 77.5 & 52.5 & 55.0 & 52.5 \\
\hline $\begin{array}{l}\text { Lack of interest in cooperation } \\
\text { from public administration } \\
\text { employees }\end{array}$ & 30.0 & 32.5 & 15.0 & 47.5 \\
\hline $\begin{array}{l}\text { Corruption, nepotism, } \\
\text { bureaucracy }\end{array}$ & 0.0 & 0.0 & 0.0 & 0.0 \\
\hline $\begin{array}{l}\text { Poor communication between } \\
\text { the office and the residents }\end{array}$ & 10.0 & 5.0 & 5.0 & 7.5 \\
\hline The way of exercising power & 2.5 & 0.0 & 0.0 & 0.0 \\
\hline
\end{tabular}

Source: Own study based on research results.

Residents were also asked about their knowledge of the city's cooperation program with non-governmental organizations. Answering this question, for the most part, respondents opined that they do not have information on the functioning of the city's cooperation program with non-governmental organizations. The highest level of lack of information in this respect was found amongst Przemyśl, Rzeszow and Tarnobrzeg local communities. Over $70 \%$ of respondents in these cities are uninformed in this matter.

Table 13 presents the councils' known forms of cooperation with non-governmental organizations. In Krosno, Przemyśl and Tarnobrzeg, the forms of cooperation between the councils and NGOs best-known to respondents are: assistance in creating the proper image of non-governmental organizations and local government including the outsourcing of projects. In Krosno, Przemyśl and Rzeszów, respondents are aware of local authority's grant/subsidies and recommendations to non-governmental organizations. Inhabitants of these three cities are also able to identify social problems within their local communities. In addition, residents in Krosno noticed that the cooperation between local authorities and NGOs creates conditions for mutual enlightenment regarding the role of councils' institutions and NGOs. Respondents in the capital of the Podkarpackie province noticed that the cooperation between local public administration and non-profit organizations encourages entrepreneurs to sponsor best projects of these organizations. 
Table 13. Forms of cooperation between councils and non-governmental organizations known to the residents

\begin{tabular}{|l|c|c|c|c|}
\hline \multirow{2}{*}{ FORMS OF COOPERATION } & \multicolumn{3}{c|}{ ANSWER STRUCTURE [\%] } \\
\cline { 2 - 5 } & $\mathbf{K}$ & $\mathbf{P}$ & $\mathbf{R Z}$ & $\mathbf{T}$ \\
\hline $\begin{array}{l}\text { Mutual enlightenment on the role of council's } \\
\text { institutions and NGOs }\end{array}$ & 15.0 & 0.0 & 0.0 & 0.0 \\
\hline Organizing special purpose funds & 0.0 & 0.0 & 0.0 & 0.0 \\
\hline $\begin{array}{l}\text { Help in creating the proper image of NGOs and } \\
\text { local governments }\end{array}$ & 32.5 & 0.0 & 0.0 & 12.5 \\
\hline Granting of subsidies & $\mathbf{3 5 . 0}$ & $\mathbf{1 7 . 5}$ & $\mathbf{2 5 . 0}$ & 0.0 \\
\hline Common identification of social problems & 0.0 & 0.0 & 0.0 & $\mathbf{1 0 . 0}$ \\
\hline Organizing training consultations, conferences & 17.5 & 0.0 & 10.0 & 0.0 \\
\hline Task outsourcing & 25.0 & 12.5 & 0.0 & 0.0 \\
\hline $\begin{array}{l}\text { Encouraging entrepreneurs to sponsor best NGO } \\
\text { projects }\end{array}$ & 0.0 & 0.0 & 20.0 & 0.0 \\
\hline $\begin{array}{l}\text { Giving recommendations to } \\
\text { non-governmental organizations }\end{array}$ & 5.0 & 0.0 & 12.5 & 0.0 \\
\hline
\end{tabular}

Source: Own study based on research results.

The spheres of cooperation between the councils and NGOs known to the inhabitants are presented in Table 14. Residents of all local governments that participated in the survey know the areas of the city's cooperation with non-governmental organizations. These include culture, health care, sport, tourism and recreation. In addition, in Krosno, Przemyśl and Tarnobrzeg, respondents pointed to such areas as: the exclusion of the elderly and the disabled, as well as social services and social assistance. In Przemyśl and Tarnobrzeg, on the other hand, the residents pointed at local community exchange education.

Table 14. The sphere of cooperation between the councils and non-governmental organizations known to the residents

\begin{tabular}{|l|c|c|c|c|}
\hline \multirow{2}{*}{ AREA OF COOPERATION } & \multicolumn{4}{c|}{ ANSWER STRUCTURE [\%] } \\
\cline { 2 - 5 } & $\mathbf{K}$ & $\mathbf{P}$ & $\mathbf{R Z}$ & $\mathbf{T}$ \\
\hline Environmental safety & 0.0 & 0.0 & 0.0 & 0.0 \\
\hline Animal safety & 0.0 & 0.0 & 0.0 & 0.0 \\
\hline Education & 0.0 & 10.0 & 0.0 & 17.5 \\
\hline Culture & 27.5 & $\mathbf{1 5 . 0}$ & 12.5 & 12.5 \\
\hline Healthcare & 15.0 & 12.5 & $\mathbf{2 7 . 5}$ & $\mathbf{2 5 . 0}$ \\
\hline Law & 5.0 & 0.0 & 0.0 & 0.0 \\
\hline $\begin{array}{l}\text { Countering the exclusion of the elderly and } \\
\text { the disabled }\end{array}$ & 20.0 & 10.0 & 22.5 & 22.5 \\
\hline Labor market & 0.0 & 0.0 & 0.0 & 0.0 \\
\hline Sport, tourism, recreation & $\mathbf{3 2 . 5}$ & $\mathbf{1 5 . 0}$ & 0.0 & 7.5 \\
\hline Social services and social assistance & 27.5 & 0.0 & $\mathbf{2 7 . 5}$ & 20.0 \\
\hline
\end{tabular}

Source: Own study based on research results. 
The respondents were, next, asked if social initiatives were supported and in what form. According to the results of the survey, residents generally do not have information about the support for social initiatives by the respective councils. In Krosno, only 5\% of people confirmed that they have such information, and they relate to co-financing social projects and organizational assistance from the office.

A manifestation of the inhabitants' involvement in the social life of the council is their knowledge about the use of participatory budget by the local administration - Table 15 . The results of the research show that over half of the residents of Przemyśl and Rzeszów have knowledge about the use of participatory budget by the council office. In the other two local governments, the inhabitants' knowledge about the implementation of the participatory budget is less.

Table 15. Respondents' knowledge of how the city council applied the participatory budget

\begin{tabular}{|c|c|c|c|c|}
\hline \multirow{2}{*}{ SPECIFICATION } & \multicolumn{4}{|c|}{ ANSWER STRUCTURE [\%] } \\
\cline { 2 - 5 } & K & P & RZ & T \\
\hline YES & 35.0 & $\mathbf{5 2 . 5}$ & $\mathbf{8 5 . 0}$ & 47.5 \\
\hline NO & $\mathbf{6 5 . 0}$ & 47.5 & 15.0 & $\mathbf{5 2 . 5}$ \\
\hline
\end{tabular}

Source: Own study based on research results.

Table 16 shows the participation of residents in activities related to the implementation of the participatory budget. Most of the surveyed residents do not participate in activities related to the implementation of the participatory budget. The turnout in such initiatives did not exceed $20 \%$ in any of the cities with poviat status in the Podkarpackie province.

Table 16. Participation of residents in activities related to the implementation of the participatory budget

\begin{tabular}{|c|c|c|c|c|}
\hline \multirow{2}{*}{ SPECIFICATION } & \multicolumn{4}{|c|}{ ANSWER STRUCTURE [\%] } \\
\cline { 2 - 5 } & $\mathbf{K}$ & $\mathbf{P}$ & $\mathbf{R Z}$ & $\mathbf{T}$ \\
\hline YES & 20.0 & 20.0 & 12.5 & 15.0 \\
\hline NO & $\mathbf{8 0 . 0}$ & $\mathbf{8 0 . 0}$ & $\mathbf{8 7 . 5}$ & $\mathbf{8 5 . 0}$ \\
\hline
\end{tabular}

Source: Own study based on research results.

Table 17 presents the categories of participatory budget projects most frequently selected by residents. Participatory budgeting can relate to various categories projects that improve residents' standard of living in a given area. Most often, respondents vote for those areas of participatory budget projects that are related to education, road infrastructure, courtyards, revitalization, sport, pedestrian and bicycle infrastructure, as well as for projects related to playgrounds.

Benefits noticed by respondents in connection with the use of civic/participatory budget are presented in Table 18. According to the respondents, the positive aspects of the functioning of the civic/participatory budget are: developing civic attitudes and increasing trust in the activities of local administration. In addition, in Krosno and Rzeszów, the respondents noted the increase in citizens' knowledge regarding the application of the 
civic/participatory budget, while in the case of Krosno and Rzeszów increased efficiency of the management of public funds received more attention.

Table 17. Categories of participatory budget projects most frequently chosen by residents

\begin{tabular}{|l|c|c|c|c|}
\hline \multirow{2}{*}{ PROJECT CATEGORIES } & \multicolumn{4}{|c|}{ ANSWER STRUCTURE [\%] } \\
\cline { 2 - 5 } & $\mathbf{K}$ & $\mathbf{P}$ & $\mathbf{R Z}$ & $\mathbf{T}$ \\
\hline Education & $\mathbf{1 7 . 5}$ & 0.0 & 10.0 & 7.5 \\
\hline Road infrastructure & 7.5 & $\mathbf{1 5 . 0}$ & $\mathbf{1 2 . 5}$ & $\mathbf{1 2 . 5}$ \\
\hline $\begin{array}{l}\text { Pedestrian and bicycle } \\
\text { infrastructure }\end{array}$ & 0.0 & 0.0 & 10.0 & 0.0 \\
\hline Collective Communication & 12.5 & 0.0 & 7.5 & 0.0 \\
\hline Playgrounds & 0.0 & 0.0 & 0.0 & 0.0 \\
\hline Courtyards & 5.0 & 10.0 & 2.5 & 0.0 \\
\hline Revitalization & 10.0 & 0.0 & 7.5 & 10.0 \\
\hline Sport & 7.5 & 10.0 & 10.0 & 0.0 \\
\hline Municipal greenery and recreation & 0.0 & 0.0 & 5.0 & 0.0 \\
\hline
\end{tabular}

Source: Own study based on research results.

Table 18. Benefits noticed by respondents in relation to the functioning of the participatory budget

\begin{tabular}{|l|c|c|c|c|}
\hline \multirow{2}{*}{\multicolumn{1}{|c|}{ BENEFITS }} & \multicolumn{3}{|c|}{ ANSWER STRUCTURE [\%] } \\
\cline { 2 - 5 } & $\mathbf{K}$ & $\mathbf{P}$ & $\mathbf{R Z}$ & $\mathbf{T}$ \\
\hline $\begin{array}{l}\text { Increased confidence in local } \\
\text { administration }\end{array}$ & $\mathbf{1 5 . 0}$ & $\mathbf{1 7 . 5}$ & 7.5 & 0.0 \\
\hline Developing civic attitudes & $\mathbf{1 5 . 0}$ & 12.5 & $\mathbf{1 2 . 5}$ & $\mathbf{1 2 . 5}$ \\
\hline $\begin{array}{l}\text { More effective financial } \\
\text { management }\end{array}$ & 10.0 & 0.0 & $\mathbf{1 2 . 5}$ & 0.0 \\
\hline $\begin{array}{l}\text { Access to information on budget } \\
\text { management }\end{array}$ & 7.5 & 0.0 & 10.0 & 0.0 \\
\hline Enhanced citizens' knowledge & 12.5 & 10.0 & 7.5 & 10.0 \\
\hline
\end{tabular}

Source: Own study based on research results.

\section{CONCLUSION}

The challenges facing local governments mean that the management of local government administration offices is increasingly turning to methods that can contribute to their better functioning (Haruta, Radu, 2010). One of these methods is the active participation of the local community in public life. Pimbert and Wakeford (2001) state that 'democracy without citizen deliberation and participation is ultimately an empty and meaningless concept'. Providing citizens with active participation in decision-making processes is becoming more and more a sign of the times. Values such as social dialogue at the local level, good local co-governance, political consensus, skilful building of social agreement around the goals of local development or dissemination of local partnership are becoming a kind of primer for every public manager (Roberst, 2004). 
The research conducted on the assessment of local administration by residents in the context of the process of social participation unfortunately showed that the local community in Podkarpackie cities with poviat status is not sufficiently oriented in this matter. Various forms of social participation are rarely used, and the main reason for this is, according to the respondents, the lack of time. However, our country lacks the tradition of social participation, and in consequence strong NGOs and active citizenship. In order for the community of a given commune to be fully democratic, local authorities should strive to encourage their residents' active participation. Civil society is one that is accustomed to being involved in matters of the common good at local and supra-local levels and actively operating in the public forum.

Respondents who participate in social participation confirmed that the most effective form of its implemented by local government administration offices is information sharing, followed by consultation. According to respondents, co-decision making is not very efficient.

Information sharing, i.e. low levels of participation, uses a one-way, passive communication mechanism. It can be limited to providing only selected information, using one communication channel. Nowadays, an entire range of tools for information sharing is available. The most commonly used by residents and offered by council offices include websites and social networking sites.

Consulting (considered as the average intensity of participation) is another form of social participation, which involves a two-way communication, i.e. a mechanism for asking, consulting opinions and obtaining feedback. Studies have shown that the inhabitants of the studied cities with poviat status in the Podkarpackie Province most often take part in such areas of consultation as draft resolutions, development strategies and social problems. The most well-known tools of social consultations to city residents are: direct meetings with residents and NGOs, meetings with specific target groups as well as meetings with expert or problem teams.

The last form of participation is participation and co-decision taking as elements of high intensity of participation, based on partnership (public-public, public-social and publicprivate), assuming symmetrical communication. The most frequently mentioned areas of co-decision taking, in which the inhabitants of all cities in Podkarpackie Province with poviat status take part include the city budget, social care, local development and spatial development. The participatory budget has been the most popular in recent years. However, due to the limited amount of funds allocated for this purpose, this form should be considered symbolic.

Research results provide practical guidance for local administration, whose activities should focus on making residents aware of the benefits of social participation. Providing residents with relevant information on the principles, forms or methods of participation may prejudge the quality of life in a given local government and the course of its development.

\section{REFERENCES}

Alexiu, T. M., Lazar, T. A., Baciu, E. L. (2011). Community participation and involvement in social actions, "Transylvanian Review of Administrative Sciences, Vol. 33.

Bradbury, J. A., Branch, K. M., Focht, W. (1999). Trust and public participation in risk policy issues [In:] Cvetkovich, G., Löfstedt, R., eds., Social Trust and the Management of Risk. Earthscan: London. 
Chirenje, I. L., Giliba, R. A., Musamba, E. B. (2013). Local communities' participation in decision-making processes through planning and budgeting in African countries. "Chinese Journal of Population Resources and Environment” No. 1, Vol. 11.

Creighton, J. L. (2005). The Public Participation Handbook: Making Better Decisions through Citizen Involvement. San Francisco: Jossey-Bass.

Edelenbos, J. and Klijn, E. H. (2005). Managing Stakeholder Involvement in Decision-Making: A Comparative Analysis of Six Interactive Processes in the Netherlands. "Journal of Public Administration Research and Theory", Vol. 16.

Fishkin, J. S. (2009). When the People Speak. Deliberative Democracy and Public Consultation, New York: Oxford University Press.

Grzebyk M., Pierścieniak A., Pytko P. (2019). Administracja lokalna w procesie partycypacji społecznej (na przykładzie miast grodzkich $w$ województwa podkarpackiego). „Studia z Polityki Publicznej” No. 3 (23).

Haruta, C., Radu B. (2010). Citizen participation in the decision making process at local and county levels in the Romanian public institutions. "Transylvanian Review of Administrative Sciences", Vol. 31E.

Innes, J. E., Booher, D. E. (2004). Reframing public participation: strategies for the $21^{\text {st }}$ century. "Planning Theory and Practice" No. 4, Vol. 5.

Irvin, R. A., Stansbury, J. (2004). Citizen Participation in Decision-Making: Is It Worth the effort. "Public Administration Review" No. 1, Vol. 64.

Kaczmarek, T. (2016). Administrative division of Poland - 25 years of experience during the systemic transformation. "EchoGéo", Vol. 35. DOI: 10.4000/echogeo.14514

Kakumba, U., Nsingo, S. (2008). Citizen participation in local government and the process of rural development: the rhetoric and reality in Uganda. "Journal of Public Administration" No. 2, Vol. 43.

Kasymova, J. (2014). Analyzing Recent Citizen Participation Trends in Western New York: Comparing Citizen Engagement Promoted by Local Governments and Nonprofit Organizations. "Canadian Journal of Nonprofit and Social Economy Research" No. 2, Vol. 5.

Kasymova, J. T., Schachter, H. L. (2014). Bringing participatory tools to a different level. "Public Performance \& Management Review" No. 3, Vol. 37.

King, C., Feltey, K. M., Susel, B. O. (1998). The question of participation: Toward authentic public participation in public administration. "Public Administration Review" No. 4, Vol. 58.

McGann, A. (2006). The logic of democracy. Reconciling Equality. Deliberation and Minority Protection. Michigan: 115.

Michels A., De Graaf, L. (2010). Examining Citizen Participation: Local Participatory Policy Making and Democracy. "Local Government Studies" No. 4, Vol. 36.

Organization for Economic Cooperation and Development, OECD, Engaging Citizens in Policy-Making: Information, Consultation and Public Participation. PUMA Policy Brief No. 10, July 2001.

Paul, S. (1987). Community Participation in Development Projects: the World Bank Experience. “World Bank Discussion Papers”, Vol. 6.

Pimbert, M. P., Wakeford, T. (2001). Overview - deliberative democracy and citizen empowerment [In:] Pimbert, M. P., Wakeford, T., eds., Deliberative Democracy and Citizen Empowerment, PLA Notes 40, IIED with the Commonwealth Foundation. ActionAid, DFID and Sida: London. 
Roberts, N. (2004). Public Deliberation in an Age of Direct Citizen Participation. "The American Review of Public Administration” No. 4, Vol. 34.

Uche, O. A., Uche, I. B., Chukwu, N-N., Nwokeoma, B. N. (2019). Membership participation and sustainability of government-driven rural development projects in Abia state of Nigeria. "Transylvanian Review of Administrative Sciences", Vol. 56E.

Wójcicki, M. (2013). Pojęcie, istota i formy partycypacji społecznej w procesie planowania przestrzennego. „Rozwój Regionalny i Polityka Regionalna”, Vol. 24.

www.cbos.pl

DOI: $10.7862 /$ rz.2021.hss.02

The text was submitted to the editorial office: June 2020.

The text was accepted for publication: March 2021. 
